\title{
UMUR SIMPAN DAN KUALITAS MIKROBIOLOGIS TELUR ITIK ASIN RENDAH SODIUM DENGAN PENGGUNAAN EKSTRAK DAUN JATI DAN PENGOVENAN
}

\author{
SHELF LIFE AND MICROBIOLOGICAL QUALITY OF SALTED DUCK EGGS PREPARED \\ WITH TEAK LEAF EXTRACT AND OVEN TREATMENT
}

\author{
Setyaningrum Ariviani, Gusti Fauza, Dwi Ishartani, Dyah Kartika Dewi \\ Program Studi Ilmu Teknologi Pangan, Fakultas Pertanian, Universitas Sebelas Maret \\ E-mail: setya_ariviani@yahoo.com; setyaningrum_ariviani@staff.uns.ac.id
}

Diserahkan [7 Oktober 2019]; Diterima [30 Januari 2020]; Dipublikasi [17 Februari 2020]

\begin{abstract}
Salted duck egg is a duck egg preservation product which nutritionally rich in unsaturated fatty acid, fat, protein, and minerals, as well as has lower phospholipids and cholesterol levels than the fresh eggs. The salting (sodium chloride, $\mathrm{NaCl}$ ) treatment during salted egg processing produces desirable egg yolk texture, salty taste, and longer the shelf life. The previous study reported that hypertension prevalence and stroke risk have a negative correlation to potassium intake but positively correlated to the sodium intake. The authors have reported the development of low-sodium salted eggs having antioxidant potential through salting process innovation by potassium chloride $(\mathrm{KCl})$ substitution and teak leaf extract addition. The potential of intensive duck eggs for low-sodium salted egg production also has been reported in the previous author's study. This research aims to evaluate the shelf life and microbiological quality of low-sodium salted eggs prepared with salting process innovation and oven treatment using intensive duck eggs. Oven treatment carried out at temperature of $100^{\circ} \mathrm{C}$ with various oven duration. The oven duration that produce low sodium salted eggs with the highest sensory quality was chosen for salted eggs preparation. The shelf life of low-sodium salted eggs was determined by measuring the sensory quality degradation during storage at ambient temperature. Microbiological quality conducted by analyze the total plate count (TPC) of low sodium salted eggs at initial and the end of shelf life. The research result showed that 30 minutes oven duration produces the highest sensory quality. The shelf life of the low sodium salted eggs prepared with 30 minutes oven duration was 12 days. The TPC of fresh prepared low sodium salted egg reach to $6.4 \times 10^{3} \mathrm{CFU} / \mathrm{g}$ and increased to $2,4 \times 106 \mathrm{CFU} / \mathrm{g}$ at the end of the shelf life. These results provide an alternative to the development of intensive duck eggs for the production of low-sodium salted eggs as innovation product of duck salted eggs which were safer and has better quality for the Indonesian community
\end{abstract}

Keywords: low-sodium salted egg, shelf life, TPC

\section{ABSTRAK}

Telur itik asin adalah produk pengawetan telur itik yang kaya akan asam lemak tak jenuh, protein, dan mineral, serta memiliki kadar fosfolipid dan kolesterol yang lebih rendah daripada telur segar. Penggaraman $(\mathrm{NaCl})$ pada proses pembuatan telur asin selain berperan memberikan rasa asin dan memperpanjang umur simpan juga membentuk tekstur kuning telur asin yang diinginkan. Studi sebelumnya melaporkan bahwa prevalensi hipertensi dan risiko stroke memiliki korelasi negatif dengan asupan potassium $(\mathrm{K})$ tetapi berkorelasi positif dengan asupan natrium $(\mathrm{Na})$. Tim peneliti dalam penelitian ini telah mengkaji pengembangan telur asin rendah sodium yang berpotensi antioksidan melalui inovasi proses pengasinan dengan substitusi kalium klorida $(\mathrm{KCl})$ dan penambahan ekstrak daun jati. Potensi telur itik intensif untuk produksi telur asin rendah sodium juga telah dibuktikan oleh tim penelitian ini. Penelitian ini bertujuan untuk mengevaluasi umur simpan dan kualitas mikrobiologis telur asin rendah sodium yang dibuat dengan inovasi proses penggaraman dan pengovenan menggunakan telur bebek intensif. Pengovenan dilakukan pada suhu $100^{\circ} \mathrm{C}$ dengan variasi waktu pengovenan $(0$, 15, 20, 25 dan 30 menit). Waktu pengovenan yang menghasilkan telur asin rendah sodium dengan kualitas sensori tertinggi dipilih untuk produksi telur itik asin rendah sodium untuk ditentukan umur simpan dan kualitas mikrobiologisnya. Umur simpan telur asin rendah sodium ditentukan dengan mengukur penurunan kualitas sensori selama penyimpanan pada suhu ruang. Kualitas mikrobiologis ditentukan dengan menganalisis jumlah lempeng total (TPC) telur asin rendah sodium pada awal dan akhir umur simpan. Hasil penelitian menunjukkan bahwa pengovenan selama 30 menit menghasilkan kualitas sensori tertinggi. Umur simpan telur asin natrium rendah yang dibuat dengan lama pengovenan 30 menit adalah 12 hari. TPC telur asin rendah sodium pasca

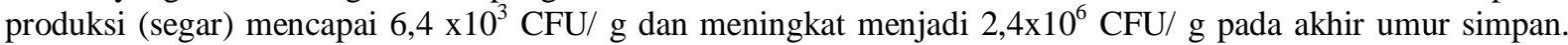
Hasil penelitian ini memberikan alternatif pengembangan telur itik intensif untuk produksi telur asin rendah sodium sebagai produk inovasi telur itik asin yang lebih aman dan memiliki kualitas lebih baik.

Kata kunci : telur asin rendah sodium, umur simpan, TPC 


\section{PENDAHULUAN}

Proses utama dalam pembuatan telur asin adalah penggaraman. Penggaraman mengakibatkan serangkaian perubahan fisiko kimia yang membentuk karakteristik telur asin yang diinginkan seperti warna kuning telur yang lebih kemerahan, tekstur kuning telur yang lembut, masir dan berminyak serta umur simpan yang lama (Xu et al., 2017; 2018; Kaewmanee et al., 2009; 2011; Benjakul dan Kaewmanee, 2017; Ai et al, 2018). Penggaraman pada proses pembuatan telur asin umumnya menggunakan garam sodium $(\mathrm{NaCl})$ yang mengakibatkan akumulasi $\mathrm{NaCl}$ di dalam kuning maupun putih telur (Xu et al., 2017; 2019; Kaewmanee et al., 2011; Benjakul dan Kaewmanee, 2017).

Konsumsi garam sodium berlebih memicu hipertensi akibat ketidakseimbangan rasio sodim dan potassium (Xu et al., 2017). Tingginya konsumsi sodium dan kurangnya asupan potassium merupakan patofisiologi hipertensi. Prevalensi hipertensi dan resiko stroke berkorelasi positif dengan asupan sodium namun berkorelasi negative dengan asupan potassium (Adrogué dan Madias, 2007). Konsumsi $\mathrm{KCl}$ terbukti mampu menurunkan tekanan darah sitosolik tikus hipertensi (McDonough dan Nguyen, 2012). Dan Ketika asupan potassium ditingkatkan, asupan garam sodium yang tinggi tidak menyebabkan peningkatan tekanan darah (Rodrigues et al., 2014). Ariviani et al. (2017) telah mengkaji pengembangan telur asin rendah sodium berpotensi antikosidan dengan substitusi garam $\mathrm{KCl}$ dan penambahan ekstrak daun jati pada adonan pengasin.

Menurut Benjakul dan Kaewmanee (2017), telur yang umum digunakan sebagai bahan baku pembuatan telur asin adalah telur itik karena cangkang telurnya yang lebih berpori dibanding telur ayam sehingga mempercepat difusi garam ke dalam telur. Telur asin dari telur itik juga memiliki karakteristik yang lebih diinginkan dibanding telur asin dari telur ayam.

Produksi telur itik di indonesia ada dua jenis berdasarkan sistem pemeliharaannya. Sistem pemeliharaan dengan sistem kandang menggunakan keseluruhan pakan buatan, disebut sistem intensif. Sistem pemeliharaan semi-intensif menggunakan sistem kandang dan diangon dengan sebagian pakan buatan dan pakan yang diperoleh selama itik diangon (Arthur, 2017). Sistem pemeliharaan intensif menghasilkan telur itik dalam jumlah yang lebih banyak dibanding sistem pemeliharaan semi-intensif (Sarworini, 2002), sehingga harga telur itik intensif lebih murah dibandingkan telur itik semi-intensif. Namun, telur asin yang dibuat dari telur itik intensif memiliki warna kuning telur yang lebih pucat dan kurang disukai dibanding yang dibuat dari telur itik semi-intensif (Akhadiarto, 2010). Kualitas telur asin selain dipengaruhi oleh karakteristik sensorisnya juga ditentukan oleh umur simpannya (Suprapti, 2002),

Ariviani et al. (2018) telah mengkaji potensi telur itik intensif sebagai telur asin rendah sodium. Hasilnya menunjukkan bahwa telur asin rendah sodium yang dibuat dari telur itik intensif dengan substitusi $\mathrm{KCl}$ $60 \%$ dan penggunaan ekstrak daun jati untuk menggantikan air pada pembuatan adonan pengasin dan dioven pada suhu $100^{\circ} \mathrm{C}$ selama 30 menit terbukti memiliki kualitas sensoris yang signifikan lebih tinggi $(\mathrm{p}<0,05)$, kadar sodium yang $39 \%$ lebih rendah, dan Aw yang signifikan lebih rendah $(\mathrm{p}<0,05)$ dibanding telur asin konvensional yang dibuat dari telur itik semi intensif tanpa substitusi $\mathrm{KCl}$ maupun penggunaan ekstrak daun jati.

Penelitian ini bertujuan untuk mengkaji umur simpan dan kualitas mikrobiologis telur asin rendah sodium dari telur itik intensif yang dibuat dengan substitusi $\mathrm{KCl} 60 \%$ dan penggunaan ekstrak daun jati pada adonan pengasinnya serta perlakuan pengovenan pada suhu $100^{\circ} \mathrm{C}$. Penelitian pendahuluan dilakukan untuk menentukan lama pengovenan yang menghasilkan telur asin rendah sodium yang memiliki kualitas sensoris yang lebih tinggi dibanding telur asin konvensional (tanpa substitusi KCL, tanpa penambahan ekstrak daun jati maupun pengovenan) yang dibuat dari telur itik semi intensif. Budiman et al. (2012) menunjukkan bahwa lama waktu penyangraian $(5,10,15$, 20 menit) setelah perebusan telur asin 
berpengaruh terhadap kadar $\mathrm{NaCl}$, rasa dan tekstur telur asin.

\section{METODE PENELITIAN}

\section{Bahan}

Bahan yang digunakan dalam penelitian ini meliputi: adalah telur itik semi intensif yang didapat dari daerah Plumbon, Karanganyar dan telur itik intensif yang didapat dari daerah Jatimalang, Sukoharjo. Garam yang digunakan ialah garam grasak yang didapatkan di Pasar legi. Batu bata didapatkan di toko bangunan daerah Semanggi, abu gosok didapatkan di warung daerah Semanggi, dan ekstrak daun jati yang dihasilkan dari daun jati yang didapatkan di daerah Pabelan, Sukoharjo. Bahan untuk analisis kualitas mikrobiologis digunakan buffered peptone water dan plate count agar produksi Oxoid (UK).

\section{Alat \\ Peralatan penelitian yang digunakan adalah peralatan untuk pembuatan telur asin, oven dengan sistem pengapian langsung, peralatan gelas, magnetic stirrer (Thermo Fisher scientific Inc., USA), perangkat uji sensoris, mikropipetor, mortar, vortex, autoklaf, inkubator (Memmert, Germany), Bio Safety Cabinet (BSC), dan colony counter.}

\section{Tahapan Penelitian}

Penelitian dilakukan dalam lima tahapan penelitian, yaitu: (1) Pembuatan telur asin rendah sodium dari telur itik intensif menggunakan adonan pengasin dengan substitusi $\mathrm{KCl} 33,3 \%$ dan penggunaan ekstrak daun jati untuk menggantikan air, dan pembuatan telur asin konvensional (kontrol) dari telur itik semi intensif tanpa substitisi $\mathrm{KCl}$ maupun ekstrak daun jati. (2) Pengovenan telur asin rendah sodium pada suhu $100^{\circ} \mathrm{C}$ dengan variasi lama pengovenan (0, 15, 20, 25 dan 30 menit). (3) Analisis kualitas sensoris (warna kuning telur, warna putih telur, aroma, rasa, tekstur, overall) telur asin rendah sodium hasil tahap ke-2 dengan uji pembedaan metode Multiple Comparison Test (Meilgaard et al., 1999) menggunakan 30 panelis tidak terlatih. Sebagai pembanding digunakan telur asin kontrol (4) analisis umur simpan telur asin rendah sodium yang dibuat dengan lama pengovenan terpilih, berdasarkan kemunduran mutu sensorisnya menggunakan uji pembedaan seperti tahap 3. Telur asin rendah sodium yang dibuat menggunakan cara dan bahan yang sama dengan lama penyimpanan 0 hari digunakan sebagai pembanding. (5) Analisis kualitas mikrobiologis dengan pengukuran TPC (AOAC, 1990) pada awal dan akhir umur simpan.

\section{Analisis Data}

Data dianalisis menggunakan ANOVA pada taraf signifikansi $\mathrm{p}<0.05$ dengan menggunakan program IBM Statistics 22 untuk melihat pengaruh perlakuan dan dilanjutkan dengan uji Duncan's Multiple Range Test (DMRT) pada tingkat signifikansi yang sama untuk mengetahui perbedaan antar perlakuan..

\section{HASIL DAN PEMBAHASAN}

\section{Penentuan Lama Waktu Pengovenan Berdasarkan Kualitas Sensoris}

Data kualitas sensoris telur asin rendah sodium dengan variasi waktu pengovenan disajikan pada Tabel 1. Lama pengovenan berpengaruh signifikan terhadap kualitas sensoris telur asin rendah sodium yang dibuat dari telur itik intensif.

Berdasarkan data kualitas sensoris pada Tabel 1 mengindikasikan bahwa pengovenan berperan dalam peningkatan kualitas sensoris telur asin rendah sodium. Hal ini terlihat dari data sampel rendah sodium tanpa pengovenan (0 menit) yang signifikan lebih rendah dibanding telur asin rendah sodium dengan waktu pengovenan 20, 25 maupun 30 menit pada semua atribut. 
Tabel 1 Kualitas sensoris telur asin rendah sodium dengan berbagai waktu pengovenan

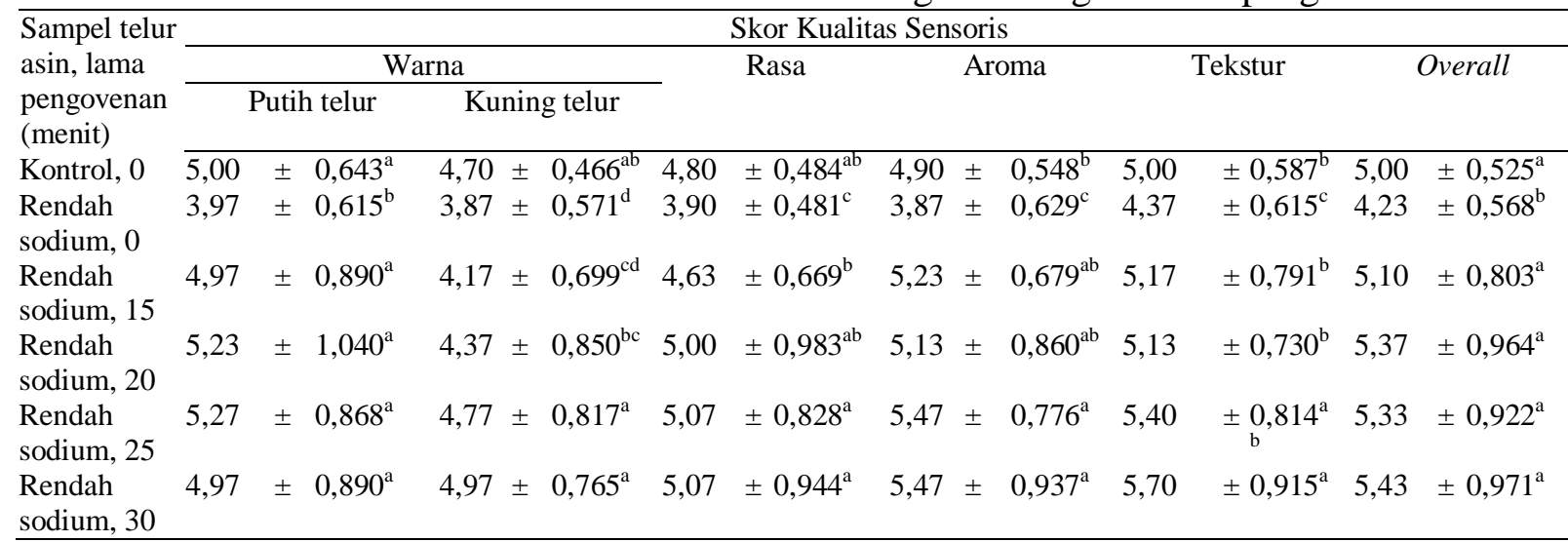

Keterangan: Angka yang diikuti huruf yang berbeda pada kolom yang sama menunjukkan beda nyata $(\mathrm{p}<0,05)$. (*) Skor 3= lebih buruk dari R, 4=agak lebih buruk dari R, 5= Sama dengan R, 6= Agak lebih baik dari R. R: telur asin control.

Kualitas sensoris telur asin rendah sodium tanpa pengovenan signifikan lebih rendah dibandingkan telur asin kontrol. Hal ini disebabkan oleh perbedaan bahan baku telur itik yang digunakan dan pengaruh substitusi KCl. Sebagaimana telah disebutkan di bagian pendahuluan, pakan yang dikonsumsi itik intensif dan semi-intensif berbeda. Perbedaan pakan berpengaruh signifikan terhadap komposisi telur itik yang dihasilkan (Ketaren dan Prasetyo, 2002; Fitasari et al., 2013, Rahman et al., 2010). Ariviani et al. (2017) menunjukkan bahwa subtitusi $\mathrm{KCl} 60 \%$ mengakibatkan penurunan kualitas warna, aroma, rasa, tektur maupun overall telur asin dari telur itik semi intensif, namun penambahan ekstrak daun jati mampu memperbaiki penurunan kualitas sensoris akibat substitusi $\mathrm{KCl}$. Pada penelitian ini penggunaan ekstrak daun jati belum mampu memperbaiki penurunan kualitas sensoris telur itik akibat substitusi $\mathrm{KCl}$ dan penggunaan telur itik intensif.

Pengovenan selama 15 menit telah mampu memperbaiki penurunan kualitas warna putih telur, aroma, rasa, tekstur dan overall, namun belum mapu memperbaiki kualitas warna kuning telur. Hal ini mengindikasikan bahwa pemekatan pigmen pada kuning telur karena penguapan air akibat pengovenan selama 15 menit belum menyebabkan peningkatan intensitas warna. Penurunan kadar air menyebabkan pemekatan pigmen pada kuning telur, sehingga intensitas warnanya akan meningkat (Kaewmanee et al., 2011)

Pengovenan mampu meningkatkan kualitas warna, aroma, rasa, tekstur, overall telur asin yang dibuat dari telur itik intensif. Peningkatan kualitas warna terkait dengan penurunan kadar air ((Kaewmanee et al., 2011). Perbaikan kualitas aroma dikarenakan perlakuan pemanasan akan menguapkan komponen volatile termasuk komponen aroma amis yang tidak dikehendaki. Peningkatan kualitas rasa terkait dengan penguapan garam selama pengovenan. Pada telur asin yang telah dioven teramati adanya garam dipermukaan kulit telur. Peningkatan kualitas tekstur akibat pengovenan dikarenakan penurunan kadar air yang menyebabkan tekstur lebih masir dan berminyak pada bagian luar kuning telur (Cheng et al., 2018). Berdasarkan data kualitas overall pada Tabel 1, waktu pengovenan yang dipilih adalah 30 menit. Hal ini dikarenakan pengovenan 30 menit menghasilkan kualitas tekstur yang signifikan lebih tinggi dibanding telur asin kontrol. Menurut Kaewmanee et al. (2009) dan Kaewmanee et al. (2011), faktor utama yang mengatur penerimaan konsumen dan permintaan pasar adalah tekstur kuning telur. Tekstur kuning telur yang masir dan yang lebih berminyak lebih disukai konsumen. 


\section{Umur Simpan Telur Asin Rendah Sodium}

Tabel 2 Skor kualitas sensoris telur asin rendah sodium pada berbagai periode penyimpanan

\begin{tabular}{lcccccc}
\hline \multicolumn{1}{c}{ Telur asin } & \multicolumn{5}{c}{ Skor Kualitas Sensoris } \\
\cline { 2 - 6 } rendah sodium & Warna putih & Warna kuning & Rasa & Aroma & Tekstur & Overall \\
\hline Baru (R) & $5.45^{\mathrm{b}}$ & $5.62^{\mathrm{b}}$ & $5.32^{\mathrm{b}}$ & $5.42^{\mathrm{b}}$ & $5.45^{\mathrm{b}}$ & $5.35^{\mathrm{b}}$ \\
Hari ke 2 & $6.28^{\mathrm{a}}$ & $6.35^{\mathrm{a}}$ & $6.32^{\mathrm{a}}$ & $6.20^{\mathrm{a}}$ & $6.12^{\mathrm{a}}$ & $6.42^{\mathrm{a}}$ \\
Baru (R) & $5.42^{\mathrm{b}}$ & $5.50^{\mathrm{b}}$ & $5.28^{\mathrm{b}}$ & $5.45^{\mathrm{b}}$ & $5.48^{\mathrm{b}}$ & $5.35^{\mathrm{b}}$ \\
Hari ke 4 & $6.20^{\mathrm{a}}$ & $6.15^{\mathrm{a}}$ & $6.35^{\mathrm{a}}$ & $6.28^{\mathrm{a}}$ & $5.95^{\mathrm{a}}$ & $6.25^{\mathrm{a}}$ \\
Baru (R) & $5.40^{\mathrm{b}}$ & $5.45^{\mathrm{b}}$ & $5.28^{\mathrm{b}}$ & $5.42^{\mathrm{b}}$ & $5.40^{\mathrm{b}}$ & $5.30^{\mathrm{b}}$ \\
Hari ke 6 & $6.12^{\mathrm{a}}$ & $6.00^{\mathrm{a}}$ & $6.28^{\mathrm{a}}$ & $6.20^{\mathrm{a}}$ & $5.88^{\mathrm{a}}$ & $6.22^{\mathrm{a}}$ \\
Baru (R) & $5.42^{\mathrm{b}}$ & $5.40^{\mathrm{b}}$ & $5.30^{\mathrm{b}}$ & $5.35^{\mathrm{b}}$ & $5.38^{\mathrm{b}}$ & $5.30^{\mathrm{b}}$ \\
Hari ke 8 & $5.98^{\mathrm{a}}$ & $5.82^{\mathrm{a}}$ & $6.12^{\mathrm{a}}$ & $6.05 \mathrm{a}$ & $5.78^{\mathrm{a}}$ & $6.12^{\mathrm{a}}$ \\
Baru (R) & $5.40^{\mathrm{b}}$ & $5.35^{\mathrm{b}}$ & $5.35^{\mathrm{b}}$ & $5.30^{\mathrm{b}}$ & $5.40^{\mathrm{b}}$ & $5.30^{\mathrm{b}}$ \\
Hari ke 10 & $5.88^{\mathrm{a}}$ & $5.80^{\mathrm{a}}$ & $6.08^{\mathrm{a}}$ & $5.98^{\mathrm{a}}$ & $5.78^{\mathrm{a}}$ & $6.15^{\mathrm{a}}$ \\
Baru (R) & $5.32^{\mathrm{a}}$ & $5.20^{\mathrm{b}}$ & $5.22^{\mathrm{b}}$ & $5.22^{\mathrm{b}}$ & $5.30^{\mathrm{b}}$ & $5.30^{\mathrm{b}}$ \\
Hari ke 12 & $5.48^{\mathrm{a}}$ & $5.45^{\mathrm{a}}$ & $5.70^{\mathrm{a}}$ & $5.65^{\mathrm{a}}$ & $5.65^{\mathrm{a}}$ & $5.58^{\mathrm{a}}$ \\
Baru (R) & $5.32^{\mathrm{a}}$ & $5.18^{\mathrm{a}}$ & $5.22^{\mathrm{a}}$ & $5.22^{\mathrm{a}}$ & $5.30^{\mathrm{a}}$ & $5.28^{\mathrm{a}}$ \\
Hari ke 14 & $4.12^{\mathrm{b}}$ & $4.12^{\mathrm{b}}$ & $4.15^{\mathrm{b}}$ & $4.15^{\mathrm{b}}$ & $4.25^{\mathrm{b}}$ & $4.18^{\mathrm{b}}$ \\
\hline Karyyyyyy
\end{tabular}

Keterangan: Angka yang diikuti huruf yang sama pada kolom yang sama untuk hari penyimpanan yang sama menunjukkan tidak beda nyata $(\mathrm{p}<0,05)$. Skor $3=$ lebih buruk dari $\mathrm{R}, 4=$ agak lebih buruk dari $\mathrm{R}, 5=$ sama dengan R, 6= agak lebih baik dari R. R: telur asin tanpa penyimpanan.

Kemunduran mutu sensoris telur asin rendah sodium selama penyimpanan pada suhu ambient disajikan pada Tabel 2. Kemunduran mutu ditentukan dengan membandingkan kualitas warna putih dan kuning telur, aroma, rasa, tekstur dan overall telur asin rendah sodium yang telah disimpan selama 2, 4, 6, 8, 10, 12, dan 14 hari penyimpanan dengan telur rendah sodium tanpa penyimpanan (0 hari).

Berdasarkan Tabel 2 pada parameter warna putih dan kuning telur, rasa, aroma, tekstur, dan overall telur asin rendah sodium mengalami penurunan kualitas pada penyimpanan hari ke 14 , pada penyimpanan hari ke 2 sampai hari ke 12 telur asin rendah sodium masih memiliki kualitas yang masih sama dengan tanpa penyimpaan (0 hari). Hasil ini memperlihatkan bahwa umur simpan telur asin rendah sodium yang dibuat dengan substitusi $\mathrm{KCl}$, penambahan ekstrak daun jati dan perlakuan oven pada suhu $100^{\circ} \mathrm{C}$ selama 30 menit adalah 12 hari. Telur asin dengan penyimpanan 0 hari dan 12 hari selanjutnya ditentukan kualitas mikrobiologisnya dengan pengukuran TPC.

\section{Kualitas mikrobiologis telur asin rendah sodium}

Tabel 3 Nilai TPC telur asin rendah sodium pada awal dan akhir masa simpan

\begin{tabular}{cc}
\hline Penyimpanan (hari) & $\begin{array}{c}\text { Nilai TPC } \\
\text { (CFU/gr) }\end{array}$ \\
\hline 0 & $6,4 \times 10^{3}$ \\
12 (akhir umur & $2,4 \times 10^{6}$ \\
simpan) & \\
\hline
\end{tabular}

Nilai TPC telur asin rendah sodium pada pentimpanan hari ke-0 (baru diproduksi) mencapai $6,4 \times 10^{3} \mathrm{CFU} / \mathrm{gr}$ dan pada penyimpanan hari ke-12 (pada akhir masa simpannya) memiliki nilai TPC $2,4 \times 10^{6}$ $\mathrm{CFU} /$ gr. Hasil penelitian ini diharapkan bisa menjadi indikator kuantitatif penentuan umur simpan telur asin rendah sodium, yaitu berdasarkan nilai TPC nya.

\section{KESIMPULAN}

Telur asin rendah sodium yang dibuat dari telur itik intensif dengan adonan pengasin yang disubstitusi $\mathrm{KCl}$ dan penambahan ekstrak daun jati dilanjutkan dengan pengovenan pada suhu 100C selama 30 menit pada telur asin rendah sodium yang 
telah direbus, memiliki kualitas sensoris yang signifikan lebih tinggi dibanding telur asin kontrol. Telur asin rendah sodium ini memiliki umur simpan 12 hari dengan jumlah total mikrobia kontaminan yang ditunjukkan dengan nilai TPC mencapai $6,4 \times 10^{3} \mathrm{CFU} / \mathrm{gr}$ pasca produksi dan $2,4 \times 10^{6}$ $\mathrm{CFU} / \mathrm{gr}$ pada akhir umur simpan.

\section{UCAPAN TERIMA KASIH}

Ucapan terimakasih kepada Kemenristek DIKTI atas pembiayaan kegiatan pengabdian melalui hibah Program Kemitraan Masyarakat (PKM) tahun 2019 dengan nomor kontrak 720/UNS.27.21/PMM/2019.

\section{DAFTAR PUSTAKA}

Adrogué HJ, dan Madias N E. (2007). Sodium and Potassium in the Pathogenesis of Hypertension.The New England Journal of Medicine 356:19661978

Ai M-M, Guo S-G, Zhou Q, Wu W-L, Jiang A-M. 2018. The Investigation of the Changes in Physicochemical, Texture and Rheological Characteristics of Salted Duck Egg Yolk during Salting. LWT - Food Science and Technology 88: 119-125. doi: 10.1016/j.lwt.2017.10.013

Akhadiarto. (2010). Pengaruh Pemberian Pakan Itik dengan Limbah Udang dan Limbah Kulit Kacang Kedelai yang Diberi Probiotik Terhadap Produksi dan Warna Kuning Telur. Jurnal Teknik Lingkungan, 11(2): 255-263.

AOAC. (1990). Official method of analysis of the association of offi cial analytical chemist $15^{\text {th }}$ Edition. Washington, DC: Association Offi cial Analytical Chemists.

Ariviani S, Fauza G, Dewi DK. (2018). Potensi Telur Itik Intensif untuk Produksi Telur Asin Rendah Sodium . Prosiding Seminar Nasional Dalam Rangka Dies Natalis UNS Ke 42 Tahun 2018, 2(1): F72-F80.
Ariviani S, Fitriasih NH, Ishartani D. (2017). Development of Low Sodium Salted Eggs and Its Antioxidant Potential. Indonesian Journal of Nutrition and Dietetics, 5(2): 51 - 59. doi: http://dx.doi.org/10.21927/ijnd.2017.5(2 ).51-59.

Arthur J. (2017). Duck Eggs. In: Patricia Y. Hester (Ed). Egg Innovations and Strategies for Improvements. Oxford: Academic Press; 2017, London, UK. hal: 23 - 32. doi:10.1016/B978-0-12800879-9.00003-2. .

Benjakul S dan Kaewmanee T. (2017). Sodium Chloride Preservation in Duck Eggs. In: Patricia Hester, editors. Egg Innovation and Strategies for Improvement, Oxford: Academic Press. p. $415-426$

Budiman A, Hintono A, Kusrahayu. (2012). Pengaruh Lama Penyangrain Telur Asin setelah Perebusan terhadap Kadar $\mathrm{NaCl}$, Tingkat Keasinan dan Tingkat Kekenyalan. Animal Agriculture Journal. 1(2): 219 - 227

Cheng S, Zhang T, Wang X, Song Y, Wang $\mathrm{H}$, Wanga $\mathrm{H}$, Yang $\mathrm{P}$, Mingqian Tan M. (2018). Influence of Salting Processes on Water and Lipid Dynamics, Physicochemical and Microstructure of Duck Egg. LWT Food Science and Technology, 95: 143149. doi: 10.1016/j.lwt.2018.04.074

Fitasari E, Kristoforus R, Nadia N. (2013). Penggunaan Kadar Protein Berbeda pada Ayam Kampung terhadap Penampilan Produksi dan Kecernaan Protein. Jurnal Ilmu-Ilmu Peternakan, 26(2):73-83.

Kaewmanee T, Benjakul S, Visessanguan W. (2009). Effect of Salting Processes on Chemical Composition, Textural Properties and Microstructure of Duck Egg. Journal of food science and Agriculture, 89(4): 625-633. DOI: $10.1002 /$ jsfa.349

Kaewmanee T, Benjakul S, Visessanguan W. (2011). Effects of Salting Processes and Time on the Chemical Composition, 
Textural Properties, and Microstructure of Cooked Duck Egg. Journal of Food Science, 76(2): S139-S147. doi: 10.1111/j.1750-3841.2010.01975.x

Ketaren, Pius P. Dan L. H. Prasetyo. 2002. Pengaruh Pemberian Pakan Terbatas terhadap Produktivitas Itik Silang Mojosari X Alabio (MA): Masa Bertelur Fase Pertama Umur 20-43 Minggu. JITV, 7(1): 38-45.

McDonough AA, dan Nguyen MTX. (2012). How does Potassium Supplementation Lower Blood Pressure? American Journal of Physiology-Renal Physiology 302: F1224-F1225. doi:10.1152/ajprenal.00429.2011

Meilgaard M, Civille GV dan Carr BT. 1999. Sensory Evaluation Techniques. Third edition, Boca Raton: CRC Press.

Rahman MM, Khan MJ, Chowdhury SD, Akbar MA. (2010). Effect of Feed Supplementation on Chemical Composition of Duck Eggs in Coastal Areas of Bangladesh. Bangladesh Journal of animal Science 39(1\&2): 163 $-169$

Rodrigues SL, Baldo MP, Machado RC, Forechi L, Molina, MCB, Mill JG. 2014. High Potassium Intake Blunts the Effect of Elevated Sodium Intake on Blood Pressure Levels. Journal of the American Society of Hypertension 8(4): 232-238.

Sarworini. 2002. Pemeliharaan Ternak Itik Secara Intensif. Balai Pengkajian Teknologi Pertanian (BPTP) Sumatera Selatan. Palembang

Suprapti, M. L. (2002). Pengawetan Telur. Kanisius. Yogyakarta

Xu L, Zhao Y, Xu M, Yao Y, Nie X, Du H, $\mathrm{Tu}$ Y. (2017) Effects of salting treatment on the physicochemical properties, textural properties, and microstructures of duck eggs. PLoS ONE 12(8): $\quad$ e0182912. https://doi.org/10.1371/journal.

Xu L, Zhao Y, Xu M,Yao Y, Nie X, Du H, $\mathrm{Tu}$ Y. (2018). Changes in aggregation behavior of raw and cooked salted egg yolks during pickling. Food Hydrocolloids $\quad$ 80: 68-77. doi:10.1016/j.foodhyd.2018.01.026

Xu L, Zhao Y, Xu M,Yao Y, Wu N, Du H, Tu Y. (2019). Changes in PhysicoChemical Properties, Microstructure, Protein Structures and Intermolecular Force of Egg Yolk, Plasma and Granule Gels during Salting. Food Chemistry 275: 600-609. doi: 10.1016/j.foodchem.2018.09.07. 